\title{
Comparative Analysis of Energy Efficiency Indicators for Residential Sectors in Egypt
}

\author{
Hafez El-Salmawy, Kamelia Youssef, Shereen Abdulla, Eman Ahmed \\ Egyptian Electric Utility and Consumer Protection Regulatory Agency \\ info@egyptera.com
}

\begin{abstract}
A number of indicators to measure Energy efficiency (EE) performance was developed by different organizations. The World Energy Council (WEC) has developed a number of indicators for measuring EE performance. The WEC residential EE indicators are; (i) $\mathrm{KWh} / \mathrm{household,} \mathrm{(ii)}$ KWh/Capita, (iii) Solar water heaters/Capita and (iv) emissions in $\mathrm{CO} 2$ (Ton)/household.

The EE indicators are developed to promote and support development, introduction and implementation of EE policies. Furthermore, the EE indicators are measured (i) to monitor changes in EE and (ii) to allow comparisons of different EE situations.
\end{abstract}

Improving EE, for electric power use in specific, will result in: 1- Better utilization of the available generation capacity to supply more customers, 2- Slow down of the power demand growth, and 3- Reduction of the investment needed for expansion of the electricity sector.

In Egypt, there are nine Electricity Distribution Companies (EDCs). Each consists of a number of geographical sectors. Each sector is further divided into districts. The district network consists of distributors, distribution transformers, and LV \& M V Lines.

Egypt era (Egyptian electric utility and consumer protection regulator agency) has collected and classified database of residential sectors for the nine companies.

There are different log sheets with information about districts and sectors. The main log sheet data for each sector acquired are:

- Monthly KWh \& No. of households for each district

- Monthly tariff category KWh \& No. of households for each sector

The EE indicators are calculated accordingly using a residential sector hierarchy based on household data, which relates between reliability of Composite Energy Indices (CEI), and the level of sector disaggregation. The residential sector covers all types of residential units. These sectors are further classified based upon nature of rural and urban area. This paper presents a set of $\mathrm{EE}$ indicators developed during five years period. The data set is used to analyze the EE indicators of Electricity consumption in different levels in residential sector. The paper compares the $\mathrm{EE}$ indicators among the different geographical regions. It discusses the criteria for the peer group selection. The paper presents the comparison on district level, and company level. Furthermore, the paper looks at the possibility of comparing the over all country EE performance to other countries.

Index Terms--Energy, Efficiency, Energy Efficiency, duration, Consumption, performance, reliability •

\section{BACKGROUND}

$\mathrm{E}$ nergy efficiency

The house hold sector includes those activities related to private dwellings (dw) it covers all energy - using activities in apartments and houses, including space and water heating, cooling, lighting and the use of appliances.

Something is more energy efficient if it delivers more services for the same energy input or the same services for less energy input. For example a CFL bulb uses less energy than incandescent bulb to produce the same amount of light therefore the CFL is considered to be more energy efficient

Energy efficiency [1] refers to the use of primary or secondary energy to produce a good of a service .Energy conservation results either from using more efficient equipment such as CFL or less energy consuming machinery or of changing behaviors such switching lights off when leaving premises.

The EE indicators are calculated accordingly using a residential sector hierarchy based on household data, which relates between reliability of composite energy indices (CEI), and the level of sector disaggregation. Fig (1) and Table (1) describe this concept.

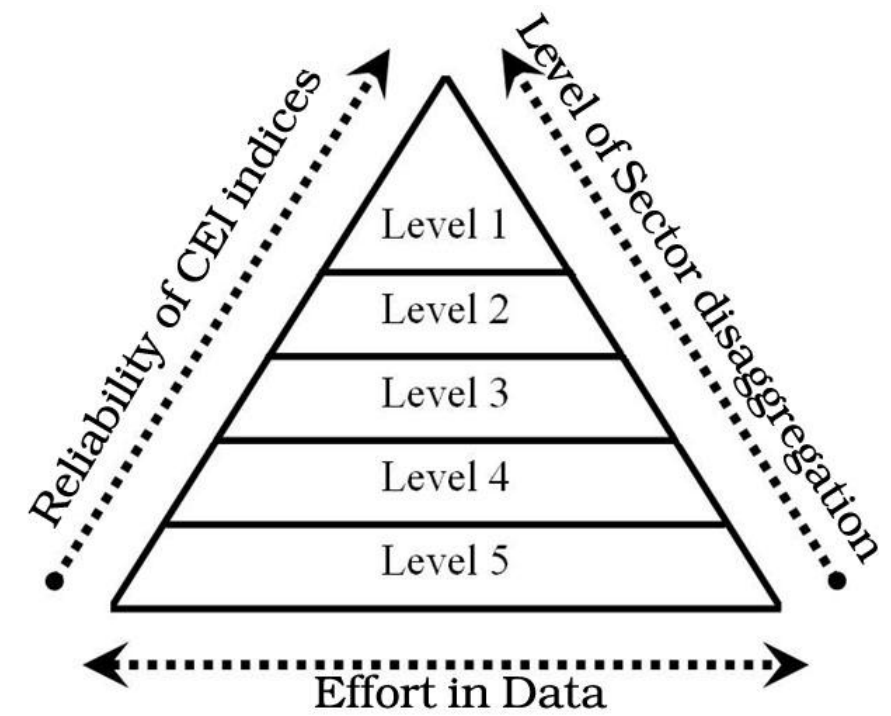

Fig (1) Data disaggregation and Reliability of CEI

Table(1) definition of facility levels in fig (1)

\begin{tabular}{|l|l|l|}
\hline \multicolumn{1}{|c|}{ Level 1 } & \multicolumn{1}{|c|}{$\begin{array}{c}\text { Reliability of } \\
\text { CEI indicators }\end{array}$} & $\begin{array}{c}\text { Level of Sector } \\
\text { disaggregation }\end{array}$ \\
\hline $\mathbf{1}$ & Lowest & Economy \\
\hline $\mathbf{2}$ & Lower & Sector \\
\hline $\mathbf{3}$ & Middle & Subsector \\
\hline $\mathbf{4}$ & Higher & Activity \\
\hline $\mathbf{5}$ & Highest & Device / Process \\
\hline
\end{tabular}

In Egypt, there are nine EDCs. Each consists of a number of geographical sectors. Each sector is further divided into districts. The district network consists of distributers, distribution transformers, and LV \& MV lines. Fig (2) 
represents residential sector pyramid based on hh(house hold) for the nine EDCs, while Fig (3) represents Residential Sector Pyramid based on hh for One EDC.

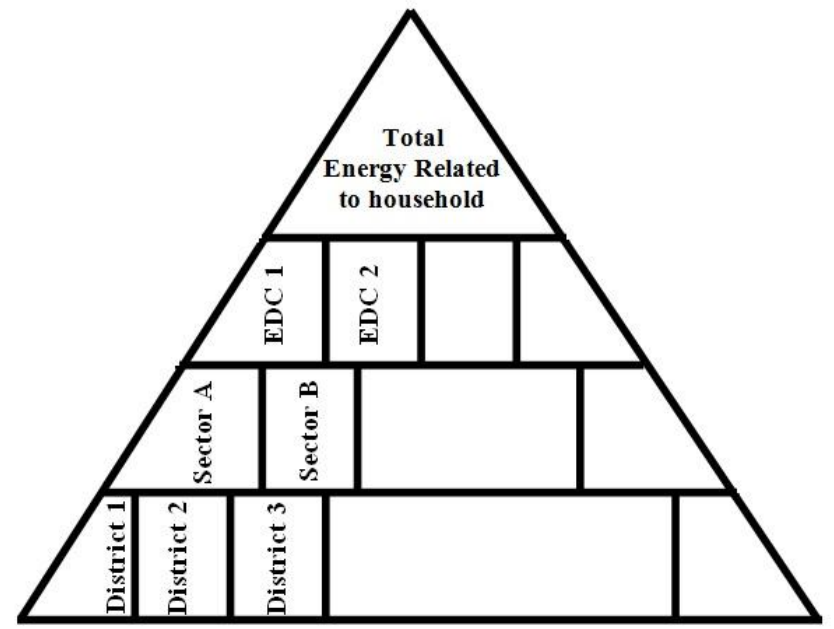

Fig (2) Residential Sector Pyramid based on household for nine EDCs

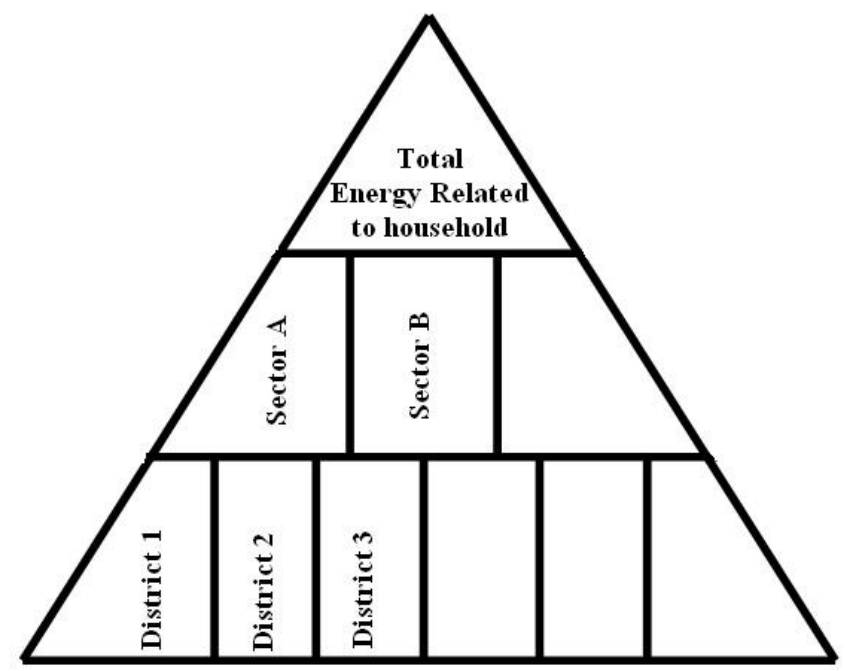

Fig (3) Residential Sector Pyramid based on household for One EDC

\section{$\mathrm{EE}$}

\section{Indicators for residential sector}

The main EE indicators are:

- Residential energy consumption / house hold (hh)

- Residential energy consumption / floor area.

Table (2) shows sets of data collected, purpose and limitation of EE indicators
Table (2) EE indicators of residential sector

\begin{tabular}{|l|l|l|}
\hline $\begin{array}{l}\text { Item } \\
\text { /indicator }\end{array}$ & $\begin{array}{l}\text { Residential energy } \\
\text { consumption /hh }\end{array}$ & \multicolumn{1}{|c|}{$\begin{array}{c}\text { Residential energy } \\
\text { consumption /floor } \\
\text { area }\end{array}$} \\
\hline $\begin{array}{l}\text { Data } \\
\text { required }\end{array}$ & $\begin{array}{l}\text { - Energy } \\
\text { consumption } \\
\text { - No. of hh }\end{array}$ & $\begin{array}{l}\text { - energy consumption } \\
\text { - total floor area }\end{array}$ \\
\hline Purpose & $\begin{array}{l}\text { - Provide a general } \\
\text { overview of the } \\
\text { trends in aggregate } \\
\text { energy intensity } \\
\text { - When energy use } \\
\text { by end - use is not } \\
\text { known energy use / } \\
\text { hh can be used as an } \\
\text { energy intensity } \\
\text { indicator }\end{array}$ & $\begin{array}{l}\text { - Monitor energy use in } \\
\text { the residential sector } \\
\text { - Combined with } \\
\text { energy use per hh } \\
\text { provides useful insights } \\
\text { on what might have } \\
\text { been the main driver of } \\
\text { energy consumption }\end{array}$ \\
\hline Limitation & $\begin{array}{l}\text {-Does not measure EE } \text { development } \\
\text {-Influence by many factors not related to EE }\end{array}$ \\
\hline
\end{tabular}

\section{$\mathbf{E}$ and $\mathrm{CO}_{2}$ indicators}

According to World Energy Council [3], the EE indicators for households are:

- Average electricity consumption of households per capita (AECH/ capita) (in KWh/cap)

- Average electricity consumption of electrified households (AECEH)(in KWh/hh)

- Electricity consumption for electrified households with $\mathrm{CC}$ (ECEH with CC)(in KWh/hh)

- Electricity consumption for electrical appliances and heating $(\mathrm{ECEAH})($ in $\mathrm{KWh} / \mathrm{hh})$

- Electricity consumption for thermal use (ECTU)(in $\mathrm{kWh} / \mathrm{hh}$ )

- $\mathrm{CO} 2$ emission of residential sector per house hold (CO2 ERS)(in $\mathrm{CO}_{2} / \mathrm{dw}$ )

Table (3) shows the EE and $\mathrm{CO} 2$ indicators in some regional and countries according to [3]

Table (3) EE and CO2 indicators in some regions (countries) (2011) [3]

\begin{tabular}{|c|c|c|c|c|c|c|}
\hline $\begin{array}{c}\text { Indicators/ } \\
\text { region country }\end{array}$ & $\begin{array}{c}\text { AECH } \\
\text { (KWh/cap) }\end{array}$ & $\begin{array}{c}\text { AECEH } \\
(\mathrm{kwh} / \mathrm{hh})\end{array}$ & $\begin{array}{c}\text { ECEH } \\
\text { with CC } \\
(\mathrm{kwh} / \mathrm{hh})\end{array}$ & $\begin{array}{c}\text { ECEAH } \\
\text { (kwh/hh) }\end{array}$ & $\begin{array}{c}\text { ECTU } \\
(\mathrm{kwh} / \mathrm{hh})\end{array}$ & $\begin{array}{c}\mathrm{CO}_{2} \text { ERS } \\
\text { (ton } \\
\mathrm{CO}_{2} / \mathrm{dw} \text { ) } \\
\end{array}$ \\
\hline World & 726 & 3338 & & & & 0.992 \\
\hline $\begin{array}{c}\text { European } \\
\text { union }\end{array}$ & 1611 & 3888 & & & & 1.84 \\
\hline Europe & 1544 & 4209 & & & & 1.96 \\
\hline Italy & 1153 & 2735 & 2740 & & & 1.87 \\
\hline Portugal & 1328 & 3510 & 3560 & & & 0.51 \\
\hline Luxemburg & 1776 & 4439 & 5137 & & & 4.02 \\
\hline US & 4569 & 11789 & 11569 & & & 2.64 \\
\hline Middle east & 1458 & 9093 & & & & 4.31 \\
\hline Saudi Arabia & 3884 & 20926 & 21138 & 8370 & 12556 & 0.757 \\
\hline China & 426 & 1308 & 1303 & 1179 & 130 & 0.753 \\
\hline India & 139 & 778 & 760 & 690 & 66.9 & 0.3 \\
\hline Africa & 170 & 2011 & & & & 0.253 \\
\hline South Africa & 842 & 4380 & & & & 0.686 \\
\hline Egypt & 651 & 2578 & 2582 & 2546 & 32.2 & 0.57 \\
\hline $\begin{array}{c}\text { United Arab } \\
\text { emirates }\end{array}$ & 3803 & 18253 & 17954 & 7301 & 10952 & \\
\hline Qatar & 3053 & & & & & \\
\hline Kuwait & 8513 & 45190 & 45653 & 18076 & 27114 & \\
\hline
\end{tabular}

From table (3)

- CO2 emissions per capita vary greatly among countries, the lowest was 0.3 t CO2 /capita in India and the greatest was 4.02 t $\mathrm{CO} 2 /$ capita in Luxemburg

- In Kuwait all EE indicators were greatest

- Kwh/ capita and kwh/hh vary greatly among countries. 
Table (4) represents the development of patterns of energy consumption in Egyptian households (1990-2011)

Table (4) Development of patterns of energy consumption in Egyptian households [3]

\begin{tabular}{|l|l|l|l|l|l|l|l|}
\hline Indicator & Unit & 1990 & 2000 & 2005 & 2009 & 2010 & 2011 \\
\hline AECH & kwh/cap & 235 & 348 & 457 & 595 & 633 & 651 \\
\hline AECEH & Kwh/hh & 1214 & 1590 & 1943 & 2413 & 2536 & 2578 \\
\hline $\begin{array}{l}\text { ECEH With } \\
\text { CC }\end{array}$ & Kwh/hh & - & - & 1945 & 2411 & 2530 & 2582 \\
\hline ECEAH & Kwh/hh & 1207 & 1571 & 1921 & 2383 & 2504 & 2546 \\
\hline ECTU & Kwh/hh & 7.36 & 18.5 & 21.7 & 30 & 31.1 & 32.2 \\
\hline CO2 ERS & $\begin{array}{l}\text { Ton } \\
\text { CO }_{2} / \text { dw }\end{array}$ & $\mathbf{0 . 7 9 9}$ & $\mathbf{0 . 6 8 8}$ & $\mathbf{0 . 6 6 4}$ & $\mathbf{0 . 7 4 8}$ & $\mathbf{0 . 7 3 2}$ & $\mathbf{0 . 5 7 0}$ \\
\hline
\end{tabular}

*CC: capital cost

From table (4)

The annual \% rate through $2000 / 2011$ for $\mathrm{kWh} / \mathrm{cap}$ is $5.9 \% /$ year and $4.5 \% /$ year for electrified households (kwh/hh) [3].

According to annual data in [4], the development of residential sector indicators for Egypt are summarized in table (5)

Table (5) Development of residential sector indicator for Egypt [4]

\begin{tabular}{|l|l|l|l|l|l|l|}
\hline Item & $\begin{array}{l}2011 / \\
2012\end{array}$ & $\begin{array}{l}2010 \\
\text { I } \\
2011\end{array}$ & $\begin{array}{l}2009 / \\
2010\end{array}$ & $\begin{array}{l}2008 / \\
2009\end{array}$ & $\begin{array}{l}2007 / \\
2008\end{array}$ & $\begin{array}{l}2006 / \\
2007\end{array}$ \\
\hline $\begin{array}{l}\text { Energy } \\
\text { sold } \\
\text { (Gwh) }\end{array}$ & $\mathbf{5 6 6 6 4}$ & $\begin{array}{l}\mathbf{5 1 3 7} \\
0\end{array}$ & 47431 & 43811 & 40271 & 36596 \\
\hline $\begin{array}{l}\text { No. of } \\
\text { custo- } \\
\text { mers }\end{array}$ & 19823502 & $\begin{array}{l}1946 \\
4312\end{array}$ & 18800239 & 18128353 & 16968095 & 15848540 \\
\hline Kwh/hh & 2858.43 & $\begin{array}{l}2639 . \\
18\end{array}$ & 2522.89 & 2416.71 & 2373.34 & 2309.11 \\
\hline
\end{tabular}

Table (6) development of kwh/hh/y for EDCs

\begin{tabular}{|l|l|l|}
\multirow{2}{*}{} & \multicolumn{2}{|c|}{$\mathrm{Kwh} / \mathrm{hh} / \mathrm{y}$} \\
\cline { 2 - 3 } & $2010 / 2011$ & $2011 / 2012$ \\
\hline EDC1 & 3029 & 3029 \\
\hline EDC2 & 2880 & 3532 \\
\hline EDC3 & 3114 & 2982 \\
\hline EDC4 & 2919 & 3035 \\
\hline EDC5 & 2269 & 2442 \\
\hline EDC6 & 3121 & 3306 \\
\hline EDC7 & 2364 & 2762 \\
\hline EDC8 & 2039 & 2175 \\
\hline EDC9 & 197 & 212 \\
\hline
\end{tabular}

Table (6) represents the $\mathrm{kwh} / \mathrm{hh} / \mathrm{y}$ for each EDCs during 2010:2012

From table (5) \& (6):

A kwh/hh/y not vary among EDCs except EDC9, also closed to results in table (5)

Geographical survey

Some of the necessary data to establish EE indicators for all geographical area of Egypt are carried out. The First Survey collected information about KWh and number of hh in EDC6. EDC6 has 7 geographical sectors, the outcome EE indicators $(\mathrm{KWh} / \mathrm{hh} / \mathrm{y})$ are summarized in table (7) for 20082011. The Second Survey collected information about area (in $\mathrm{m}^{2}$ ) for hh and annual energy consumption (2011). Types of dominated loads are: air conditions, lighting, refrigerators, freezers, clothes washers, TVs, and computers. Data used to calculate $\mathrm{kWh} / \mathrm{hh} / \mathrm{y}$ and $\mathrm{kWh} / \mathrm{m}^{2} / \mathrm{y}$. Table (8) summarizes the outcome of EE indicators for 9 EDCs in Egypt.

Table (7) EE indicators (kwh/hh/y) for EDC6 and its sectors

\begin{tabular}{|l|l|l|l|l|}
\hline sector & 2008 & 2009 & 2010 & 2011 \\
\hline Sector(1) & 1836.1 & 2437.2 & 2500.2 & 2563.5 \\
\hline Sector(2) & 2093.5 & 2709.6 & 2852.9 & 2840.7 \\
\hline Sector(3) & 1622.6 & 2349.6 & 2389 & 2393.6 \\
\hline Sector(4) & 1739.7 & 2250 & 2397 & 2350.4 \\
\hline Sector(5) & 1844.1 & 2558.4 & 2641.8 & 2669.8 \\
\hline Sector(6) & 2029 & 2408.4 & 2866.7 & 2911.2 \\
\hline Sector(7) & 1797.4 & 2314.8 & 2568 & 2610.5 \\
\hline EDC6 & 1858.91 & 2475.43 & 2602.23 & 2619.96 \\
\hline
\end{tabular}

Table (8) EE indicators for $352 \mathrm{hh}$

\begin{tabular}{|l|l|l|l|}
\hline EDC & $\begin{array}{l}\text { No. of } \\
\text { samples }\end{array}$ & $\begin{array}{l}\text { Kwh/house } \\
\text { hold } / \text { year }\end{array}$ & $\mathbf{K w h} / \mathbf{m}^{2 / \mathbf{y}}$ \\
\hline EDC 1 & $\mathbf{5 1}$ & $\mathbf{3 7 4 6}$ & $\mathbf{4 0 . 2 2}$ \\
\hline EDC 2 & $\mathbf{4 3}$ & $\mathbf{3 7 0 1}$ & $\mathbf{3 8 . 4}$ \\
\hline EDC 3 & $\mathbf{1 8}$ & $\mathbf{3 6 1 6 . 1}$ & $\mathbf{3 2 . 7}$ \\
\hline EDC 4 & $\mathbf{5 7}$ & $\mathbf{3 1 4 3 . 4}$ & $\mathbf{3 6 . 1 4}$ \\
\hline EDC 5 & 77 & $\mathbf{6 1 2 2 . 5}$ & $\mathbf{5 5 . 3 4}$ \\
\hline EDC 6 & $\mathbf{3 7}$ & $\mathbf{3 7 8 0 . 5}$ & $\mathbf{4 3 . 3 6}$ \\
\hline EDC 7 & $\mathbf{5 6}$ & $\mathbf{3 3 4 0 . 2 5}$ & $\mathbf{3 6 . 1}$ \\
\hline EDC 8 & $\mathbf{2 0}$ & $\mathbf{3 5 6 3 . 6}$ & $\mathbf{4 0 . 8 2}$ \\
\hline EDC 9 & $\mathbf{5}$ & $\mathbf{5 0 4 0}$ & $\mathbf{3 0 . 4}$ \\
\hline Average & $\mathbf{4 0 0 6}$ & $\mathbf{3 9 . 3}$ \\
\hline
\end{tabular}

Table (9) Results of questioners for 328 in Egypt according to no. of samples in tariff structure $(2011 / 2012)$

\begin{tabular}{|l|l|l|l|l|l|}
\hline & $2^{\text {nd }}$ & $3^{\text {rd }}$ & $4^{\text {th }}$ & $5^{\text {th }}$ & $6^{\text {th }}$ \\
\hline $\begin{array}{l}\text { No.of } \\
\text { customers }\end{array}$ & 44 & 110 & 81 & 37 & 23 \\
\hline $\begin{array}{l}\text { Average of } \\
\text { W/m }\end{array}$ & 4.415 & 5.36 & 4.1 & 4.96 & 8.672 \\
\hline $\begin{array}{l}\text { Average of } \\
\mathrm{kwh} / \mathrm{hh} / \mathrm{y}\end{array}$ & 2343. & 3350.9 & 4830.2 & 6681.43 & 11337.24 \\
\hline $\begin{array}{l}\text { Average of } \\
\mathrm{kwh} / \mathrm{m}^{/ 2}\end{array}$ & 26.35 & 34.93 & 45.0 & 57.41 & 97.84 \\
\hline
\end{tabular}

Source of questionnaire Egypt ERA

Table (9) shows the results for $328 \mathrm{hh}$ in Egypt according to tariff structure.

The structure of electricity tariff applied in Egypt for the residential sector is divided to 6 tariff levels, starting from "first 5 kwh monthly" to "more than $1000 \mathrm{kWh}$ monthly.

The notes from tables (7), (8), (9) are:

. EE indicators vary greatly among EDCs

- Average kwh/hh/y (in table (7)) greater than all values in other tables

.kwh/hh/y for EDC6 according to table (7) smaller than its values in tables $(8,9)$

- Average $\mathrm{kwh} / \mathrm{m}^{2}$ increase rapidly according to increase tariff structure 
Conclusion

The expansion of the survey is a positive step in developing a residential energy data base and assessing trends in EE. The EE indicators calculated according to level 1, as hierarchy based on hh data, are less accurate than according to level 5. These results are highlight for calculated $\mathrm{kWh}$ $/ \mathrm{hh} / \mathrm{y}$ according to different calculation levels: Egyptian hh, EDCs hh, samples of sectors of EDC6, and according to tariff structure.

\section{REFERENCES:}

[1] Tapping a hidden resource, Energy Efficiency in Middle East and North Africa February 2009

Energy sector management assistance program (ESMAP)

[2] Special feature European energy efficiency tends house hold energy consumption www.odyssee-indicators .org

[3] World Energy Council, energy efficiency indicators www.wec.indicators.enerdata.eu/world.php

[4] Annual reports of EEHC (2006:2011)

\section{BIOGRAPHIES}

Shereen Abdulla was born in Cairo, Egypt, on April 15, 1981. She finished her secondary school in 1998, and then studied Electrical Engineering in Cairo University to graduate in 2004. Her employment experience includes Energy Research Centre and Egypt Era (Egyptian Electric Utility and Consumer Protection Regulatory Agency).

Eman Ahmed was born in Cairo, Egypt, on September 5, 1988. She

finished her secondary school in 2005, and then studied Electrical

Engineering in Ain Shams University to graduate in 2010. Her employment

experience in Egypt Era (Egyptian Electric Utility and Consumer

Protection Regulatory Agency)from 2010 till now 